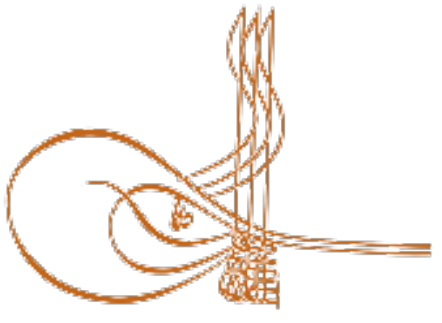

www.turkishstudies.net/language
Turkish Studies - Language and Literature

eISSN: $2667-5641$

Research Article / Araştırma Makalesi

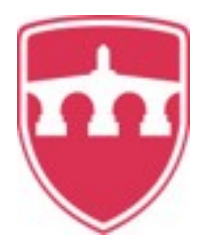

INTERNATIONAL

BALKAN

UNIVERSITY

Sponsored by IBU

\title{
Tanzimat Şiirinde Üstatlar ve Talebeleri ${ }^{1}$
}

Masters and Students in Tanzimat Poetry

\author{
Mehmet Ali Gündoğdu*
}

\begin{abstract}
A classical literature that lasted for six hundred years ended in the 19th century and a new literature developed under the influence of the West was formed in this period. The chain of a master-student, who continued unabated for almost a century, played an important role in the formation of new poetry, new genres, and ideas and emotions operating in the background of them. The first ring of the chain was Şinasi, which started its literary activities under the shadow of the mighty pashas of the period and was educated in Europe. Subsequent writers walked the new path he has opened. Namık Kemal was the writer who revolved around all the literary movements of the period and gave a permanent shape to the new literature extending towards the Republic; apart from Şinasi, it has been under the influence of mystical and classical influences and has been fed from a very rich source. Recaizade Mahmud Ekrem and Abdülhak Hamid started their literary activities as the students of Namik Kemal, but they followed different routes at certain points and prepared Edebiyat-1 Cedide movement. Against the purpose of literature that should be beneficial to society and human beings by Namik Kemal, Recaizade Mahmud Ekrem's saying that everything that is beautiful from monad to the sun can be the subject of poetry has been an important breaking point in the history of New Turkish Literature. The first mature works of the New Literature were published by Servet-i Fünun journal and followed by Recaizade. This new understanding of poetry date back to the Republic with Ahmet Haşim. In this article, these chain rings, which constitute a new literature, are introduced and the examples show how successors follow their predecessors and where they dissociate.
\end{abstract}

Structured Abstract: After the proclamation of the Tanzimat Edict of 1839, a major breakthrough in Ottoman culture and literature began. While a classical literature, which was the continuation of the old for centuries, weakened, a new literature developed under the influence of the West became increasingly strong. Certainly, the transfer of different experiences from generation to generation has played an important role in the emergence of such a culture and art move that had both traces and innovations based on the West. When we look at the period in the context of master-student or master-apprentice relationship, the existence of art-culture rings, which continue in the form of a chain, is immediately visible.

\footnotetext{
${ }^{1}$ Bu makale İNCSOS Üsküp'te sunulan sözlü bildirinin makale formatında hazırlanmış halidir.

* Dr. Öğr. Üyesi, İstinye Üniversitesi, Fen-Edebiyat Fakültesi, Türk Dili ve Edebiyatı Bölümü, Yeni Türk Edebiyatı.

Asst. Prof. Dr., Istinye University, Faculty of Arts and Sciences, Department of Turkish Language and Literature, Modern

Turkish Literature

ORCID 0000-0002-5856-1447

maligundogdu@yahoo.com

Cite as/ Atıf: Gündoğdu, M. A. (2020). Makale bașlığ1, Turkish Studies - Language, 15(1), 131-140.

https://dx.doi.org/10.29228/TurkishStudies.39402

Received/Geliş: 21 October/Ekim 2019

Accepted/Kabul: 24 March/Mart 2020

Copyright à INTAC LTD, Turkey

Checked by plagiarism software

Published/Yayın: 30 March/Mart 2020

CC BY-NC 4.0
} 
In the Ottoman Empire, art and cultural works were carried out by statesmen for centuries. They were also the first initiators of the innovation movements in the 19th century in such a cultural structure led by sultans and pashas. The statesmen who went to Europe as ambassadors or in various positions and who were keen on ideas and art were the driving forces of innovation especially in the first half of this century. In the second half of the century, their share in the first emergence of the intellectual writers of the period is very important. Intellectual statesmen who knew the West well, such as Mustafa Reşid Pasha, Sadık Rıfat Pasha, Mustafa Sami Pasha, Suphi Pasha, Akif Pasha and Ethem Pertev Pasha, were instrumental in the development of many bright young people by turning their mansions into a lore of knowledge. There are even statesmen such as Yusuf Kamil Pasha, Ahmed Vefik Pasha, Munif Pasha, Ziya Pasha, who grew up in these mansions and were both statesmen and appeared in art activities in the second half of the century. Starting the first innovations in Turkish Literature during the Tanzimat period, Şinasi recognized the West under the auspices of these intellectuals and wrote his works.

Şinasi-Namık Kemal school is the first fundamental ring that we can think of in the context of the relationship between the master and the student in the New Turkish Literature. Namik Kemal worked together with Şinasi whom he knew while he was wandering among the antiquarians in Beyazit, from 1861 to 1865. Şinasi leads Namık Kemal on simple language, dealing with social issues, the idea of progress and new themes from the West. Namik Kemal, who revolves around the literary movements of the period, feeds not only from Şinasi but also from very different sources. The first effect we can think of in the context of the master-student in him comes from the Leskofçalı Galip with whom he was in the Encümen-i Şuarâ. Kemal, who was under the influence of classical poetry in this period, always opposed the old ones in the later periods, although it shows this classical effect in all fields from poetry to play and novel. For example, the descriptions of Çamlica at the beginning of the novel "Intibah" have a classical effect. While telling the love of Adil Shah and Perihan in his novel "Cezmi", he mades many depictions parallel to the love stories in the old mesnevis. Another area of influence on Kemal was Sheikh Ahmed Efendi whom he knew in exile in Famagusta. This unity between the years 1872 and 1875 had a significant effect on the maturation of the ideas of the unity of Islam and liberty which Kemal frequently used in his works.

Namık Kemal tried to educate Recaizade Mahmud Ekrem and Abdülhak Hamid with letters sent from his exile in order to carry his thoughts about creating a new literature to the next generation. Kemal, Ekrem and Hamid, who communicate with each other from distant places by letters, had a highly literary relationship. Although Kemal could not adopt his own social and political ideas very much, he fulfilled the duty of a perfect bridge between Şinasi and them in the new field of poetry. He said that he works more in prose, he cannot give the new poem the shape he wants, and they should try to make new savings on the poem. He gave him advice on how Hamid tried the syllable meter in the verse play "Nesteren" but was not very successful. Kemal's play, especially "Celaleddin Harzemşah", played an important role in Abdulhak Hamid's turning to historical plays. In this line, Hamid wrote five plays, most of which are verses about Andalusia and Ilkhanians. When we look at the content of these plays, especially "Tarlk", the effect of Kemal's exciting and fiery style is immediately noticed. In addition, Hamid wrote his poem titled "Kabr-i Selim-i Evvel'i Ziyaret", which he praised Yavuz Sultan Selim and sent to Kemal. Kemal liked the poem and immediately sent a letter to Hamid. In his letter he expressesed his satisfaction with Hamid's interest in historical issues and asks him to do what he did in the prose field and that he do it in the field of verse. Kemal warns him by showing the imperfections of Recaizade's poems, which deal with the issues of death and nature. Among the works of Recaizâde, the one which Kemal was much most interested in, was his rhetorical book "Talim-i Edebiyat". Kemal appreciated Recaizade and made comments about the literary issues of the period in the book of "Talim-i Edebiyat Üzerine Risale", which was found among the dictates of Kemal after his death and turned into a book.

Just as Kemal left and departed from Şinasi on some issues, there were issues that Ekrem fell apart from Kemal. Recaizade Mahmud Ekrem's statement that anything beautiful from atomic to the sun can be the subject of poetry, despite the aim of Namık Kemal that literature should be beneficial to society and human, was an important breaking point in the history of New Turkish Literature. Recaizade with these views expressed in the books of "Talim-i Edebiyat" and "Takdir-i Elhan" removed the field of poetry from being social and brought it closer to the aesthetic field. This difference caused that the next generation moved away from Kemal, quit his social themes and issues and turned to being individual, direct aesthetic forms.

Keywords: Modern Turkish Literature, Tanzimat Literature, Namık Kemal, Şinasi, Abdülhak Hamid, Recaizade Mahmud Ekrem

Turkish Studies - Language, 15(1) 
Öz: Altı yüz yıl devam eden bir klasik edebiyat 19. yüzyılda son bulmuş ve Batı etkisinde gelişen yeni bir edebiyat bu dönemde şekillenmiştir. Yeni şiirin, yeni türlerin ve bunların arka planında işleyen fikir ve duyguların oluşmasında neredeyse bir yüzyıla yakın kesilmeden devam eden bir üstad-talebe zinciri önemli rol oynamıştır. Zincirin ilk halkası dönemin kudretli paşalarının gölgesinde edebî faaliyetlerine başlayan ve Avrupa tahsili gören Şinasi' dir. Sonraki yazarlar onun açtığı yeni yolda yürürler. Namık Kemal, dönemin bütün edebiyat hareketlerini çevresinde döndüren ve Cumhuriyet'e doğru uzanan yeni edebiyata kalıcı bir şekil kazandıran yazardır; Şinasi' den başka mistik ve klasik etkilerin altında da kalmış, oldukça zengin bir kaynaktan beslenmiştir. Recaizade Mahmud Ekrem ve Abdülhak Hamid ise Namık Kemal'in öğrencileri olarak edebî faaliyetlerine başlamışlar, ancak daha sonra belli noktalarda farklı rotaları izleyerek Edebiyat-ı Cedide akımını hazırlamışlardır. Namık Kemal'in edebiyatın topluma ve insana faydalı olması gerektiği amacına karşı, Recaizade Mahmud Ekrem'in zerreden şümûsa kadar güzel olan her şeyin şiirin konusu olabileceğini söylemesi Yeni Türk Edebiyatı tarihinde önemli bir kırılma noktası olmuştur. Yeni Edebiyat'ın ilk olgun eserlerini Servet-i Fünun dergisi etrafında toplanan ve Recaizade'nin izinden giden yazarlar vermişlerdir. Ahmet Haşim'le bu yeni şiir anlayışı Cumhuriyet'e kadar uzanmıştır. Bu makalede yeni bir edebiyatı oluşturan bu zincir halkaları tanıtılmış ve örneklerle haleflerin selefleri nasıl takip ettikleri ve hangi noktalarda ayrıştıkları gösterilmiştir.

Anahtar Kelimeler: Yeni Türk Edebiyatı, Tanzimat Edebiyat1, Namık Kemal, Şinasi, Abdülhak Hamid, Recaizade Mahmud Ekrem

\section{Giriş}

1839 yılı Tanzimat Fermanı'nın ilanından sonra Osmanlı kültür ve edebiyat hayatında esaslı bir yenilik hamlesi başlar. Yüzyıl boyunca eskinin devamı olan klasik bir edebiyat zayıflarken, Batı etkisinde gelişen yeni bir edebiyat giderek kuvvetlenir. Hem eskiden izler taşıyan hem de Batı merkezli pek çok yenilik içeren böyle bir kültür ve sanat hamlesinin ortaya çıkmasında muhakkak ki farklı tecrübelerin nesilden nesile aktarımı son derece önemli bir rol oynamıştır. Üstat-talebe ya da usta-çırak ilişkisi bağlamında döneme baktığımız zaman adeta zincir şeklinde devam eden sanatkültür halkalarının varlığı hemen göze çarpar.

Osmanlı Devleti'nde sanat ve kültür işleri yüzyıllar boyunca genellikle devlet adamlarının eliyle yürütülmüştür. Sultanların ve paşaların başını çektiği böyle bir kültürel yapı içerisinde 19 . yüzyılda gerçekleşen yenilik hareketlerinin ilk başlatıcısı rolünde de yine onlar vardır. Sefir olarak ya da çeşitli görevlerle Avrupa'ya giden, fikir ve sanata meraklı devlet adamları özellikle bu yüzyılın ilk yarısında yeniliğin sürükleyicisi pozisyonundadırlar. Asrın ikinci yarısına geçerken de dönemin aydın yazarların ilk ortaya çıkmasında onların payı oldukça önemlidir. Mustafa Reşid Paşa, Sadık Rıfat Paşa, Mustafa Sami Paşa, Suphi Paşa, Akif Paşa ve Ethem Pertev Paşa gibi Batı'yı iyi tanıyan aydın devlet adamları özellikle İstanbul'da kendi konaklarını bir ilim irfan yuvası haline getirerek parlak pek çok gencin yetişmesine vesile olmuşlardır. Hatta bu konaklarda yetişerek hem devlet adamı olan hem de asrın ikinci yarısında sanat faaliyetlerinde boy gösteren Yusuf Kamil Paşa, Ahmed Vefik Paşa, Münif Paşa, Ziya Paşa gibi devlet adamları da çoktur.

\section{2. Şinasi’nin Üzerinde Etkiler}

Dönemin ilk yenilik hamlelerini başlatan Şinasi'nin hayatı bilinmezlerle dolu olmakla beraber, yetişmesinde dönemin bahsi geçen paşalarının rolü büyüktür.

Şinasi, Mustafa Reşid Paşa'nın himayesi ile Paris'e gitmiş, Lamartin, Renan, Sacy ve Courteille gibi entelektüellerden beslenmiştir. Dönüşünde yine Reşid Paşa'nın yardımıyla memur olmuş bir yandan da edebiyat-dil faaliyetlerini devam ettirmiştir. Reşid Paşa'nın ölümünden sonra ise Yusuf Kamil Paşa onu himaye etmiştir. Bizde ilk roman çevirisi olan ve Yusuf Kamil Paşa tarafından tercüme edilen Telemak'ın Şinasi'nin matbaasında yayınlandığını unutmamak lazımdır. Bütün bunlarla beraber Şinasi'nin paşalarla nasıl bir ilişki kurduğu ve bu ilişkinin hangi boyutlara ulaştığı kayıtlarda çok açık değildir. 


\section{Namık Kemal üzerinde İlk Etkiler}

Tanzimat Edebiyatı'nın merkezinde yer alan Namık Kemal'in üzerinde Şinasi'nin önemli bir etkisi bulunmakla beraber; ondan önce Kemal'de, sonraki hayatını etkileyecek başka tesirler söz konusudur. Dedesi Abdüllatif Paşa'nın azledilmesinden sonra 1857'de Sofya'dan İstanbul'a gelen Namık Kemal, Tercüme Odası'na girerek beş yıl kadar çalışır. Türkiye'nin Batı dünyasına açılan penceresi olarak kabul edilen bu kurumda Kemal, Sadullah Paşa, Ayetullah Bey, Kanipaşazâde Rıfat gibi dönemin entelektüel genç simalarıyla beraber olur. Voltaire ve Montesquieu gibi Batılı yazarların eserlerini okur. Şinasi ile tanıştıktan sonra büyük bir hızla yeni fikirleri benimsemesinde buradaki havanın etkili olduğu tahmin edilebilir. Ancak bu dönemde 1862'ye kadar onun üzerinde etkili olan asıl topluluk, Encümen-i Şuarâ'dır. (Tanpınar, s. 262) Kemal, Ziya Paşa vasıtasıyla tanıştı̆g 1 bu topluluğun üyelerinden Hersekli Arif Hikmet Bey'in Laleli'de Çukurçeşme'deki konağında yapılan toplantılara katılır. Toplantılardaki vazifesi ise, bir hafta zarfinda topluluk üyelerinin yazmış oldukları şiirleri, öne çıkarak yüksek sesle okumaktır. Ebuzziya'ya göre sesi şiir okumaya son derece müsait ve ezberi de son derece güçlüdür. (Ebuzziya Tevfik, s. 19) Bu dönemde topluluk içerisindeki diğer şairlerle beraber gazeller kaleme alırken, önceki nesilden bir kısım şairlere de nazireler yazar. Bunların içerisinde en çok etkilendiği şair Leskofçalı Galip'tir. Kemal onu "Edîbi müşâünileyh hepimizin indinde vâcibü't-ta'zim olan hakâyik-cûlardan ve hepimizi aciz birakan nüktegûlardan idi." sözleriyle över. (Kaplan, s. 35) Tanpınar'a göre, Şinasi ile tanıştıktan ve eski şiirin dünyasını bıraktıktan sonra dahi Galib Bey'in şiirinden gelen tasavvufî lügat, bu şiirin dayandığı hayal sistemi ve davranışlar onda uzun zaman asıl şahsiyeti idare eden bir esas zemin gibi devam edecektir. (Tanpınar, s. 344) Hatta son eserlerinden biri olan Cezmi romanında bile AdilşahPerihan aşkının tasvirinde bu şairane hayal ve tasvirlerin -her ne kadar eleştirse de- onda etkili olduğu açıktır. Mehmet Kaplan, Kemal'in Hürriyet Kasidesi'nin kıvılcımını Galib'in divanında "Olup mecrûh-ı peykân-ı havâdis tâir-i devlet / Demâdem hûn akar çeşmim gibi enzâr-ı milletten" beytinden aldığını söyler. (Kaplan, s. 42) Kemal, Kani Paşazâde Rıfat Bey’e yazdığı bir mektupta Leskofçalı'nın bu beytini okuduğunda nasıl bir duygu haline kapıldığını şöyle anlatır: “Kıraatinden hâsll olan teessürümü nasıl târif edebileceğimi bilmem. Dünyada ne kadar âlâm ve ekdâr var ise cümlesi başıma üşüşüp bîihtiyar sokağa firladım. Tavr u hareketimi gören mutlaka divane zannederdi.”

\section{Sinasi-Namık Kemal Mektebi}

Yeni Türk Edebiyatı’nda üstat-talebe ilişkisi bağlamında düşünebileceğimiz ilk esaslı halka Şinasi-Namık Kemal mektebidir.

Namık Kemal'in Şinasi ile temasa geçmesi 1862 yılındadır. Bu tarihten önce herhangi bir yerde karşılaş̧ıklarına dair kesin bir bilgi yoktur. "Hangi senede olduğu hatırımda değildir, fakat zannıma göre yetmiş sekiz sene-i hicriyyesinde olacak, bir Ramazan günü kitap aramak için Sultan Bayezıt Camii avlusundaki sergilere girdim. Elime tâlik yazı litograf basma ile bir kağıt parçası tutuşturdular. Yirmi para istediler. Parayı verdim, kağılı aldım. Üstünde "Illahî" ünvanını gördüm; Derviş Yunus ilahisi zannettim. Bununla beraber okumaya başladım. O ilahî ne idi? Bilir misin ne idi? Beni yazdığım yazının şimdiki derecesine îsâl etmeye, milletin lisanını şimdiki hâle getirmeye sebeb-i müstakil olan ilahî bir ilahi idi. Sade fikre ne kadar da yakışıyor. (...) Nesren yazdığı şeyleri gördüğüm, hatta beğenmediğim Şinasi nin ilahî bir kelim olduğunu o şiirinde anladım. Fakat fikrimi edebiyat arkadaşlarıma anlatamadım. Gittim, gazetesine muîn oldum." (Uçman, s. 207) sözlerinden anlaşıldığına göre daha önce Şinasi'nin Tercüman-ı Ahval'deki makalelerini okumuş, ancak beğenmemiştir. Şiirindeki sade fikre hayran olarak ona hizmet etmeye karar vermiş̧tir. Gerçekten de Yeni Osmanlılar hareketi ile beraber Türk Edebiyatı'nda esaslı bir yenilik yapacak olan Kemal'in asıl şahsiyeti bu tanışmadan sonra şekillenir. Şinasi, Kemal için mükemmel bir hoca ve yol gösterici olur; daha sonra Kemal'in eserlerinde ve makalelerinde göreceğimiz pek çok yeni fikir Şinasi'de tohum halinde zaten vardır. Kemal için esaslı bir mektebe dönüşen Tasvir-i Efkar gazetesi 
çevresindeki bu beraberlik topu topu üç sene olmasına rağmen, onu tasavvufî semboller ve mazmun kalıplarla uğraşan sıradan bir divan şairliğinden, sosyal ve politik meselelerle uğraşan bir dava adamı kimliğine sokar ve yazılarının içeriği bütünüyle değişir. Bu dönemde gazetede yazdığı makale konularının çoğu daha önceden Şinasi tarafından üzerinde durulmuş konulardır. Halkın aydınlatılması için mektepler kurmak, eğitime önem vermek, büyük yangınlara karşı önlem almak, terakkiyi esas almak, Türk dili ve edebiyatı hakkında yeni fikirler ortaya koymak gibi konular hakkındaki yazılarının hemen çoğunda Şinasi’nin belirgin etkisi vardır.

Kemal Şinasi'den koptuğu, fikir noktasında ondan çok uzaklaştığı dönemlerde bile onun hakkını teslim eder. 1874'te Manastırlı Rıfat Bey'e gönderdiği mektupta Şinasi'nin altı yüz senedir insanları tutsak eden eskilerin ağır, ağdalı yazı kurallarını yerle bir ettiğini; dilimize sade, anlaşılan cümleyi, ifadeyi getirdiğini vurgular: “İnsan, gözüne yeni karalanmış bir kağıt göründükçe, Şinasi'ye nasıl rahmet okumaz ki, üdebâmızı altı yüz seneden beri enîn ü ızdırap içinde tutan ve adına usûl-i kalem yahut kâide-i rabt denilen zencir-i esareti âhen destâne bir darbe-i himmet ile paraladl." (Göçgün, s. 168)

Tanzimat'ın ikinci nesil edebiyatının usta kalemlerinden Abdülhak Hâmid, Şinasi ile Kemal arasındaki üstad-talebe ilişkisinin edebiyatımıza çok şey kazandırdığını ifade eder. Recâizade Mahmud Ekrem'e yazdığı bir mektupta Hâmid, Şinasi’nin en büyük eserinin Kemal olduğunu vurgular: "Filvaki Şinasi ne idi; ne olsa o bizim memleketimizde hiçbir şey olmaz idi; anın en büyük fazileti, Kemal'i meydana çıkarmasıdır. Edebiyat kütüphanesinin miftahlarını, öyle mahir bir ele vermesidir." (Tansel, s. 95)

1865 'te Şinasi'nin aniden Avrupa'ya gidip Tasvir-i Efkar'1 Kemal'e birakmasından sonra Kemal fikirlerini aktarmakta daha cesur davranmaya ve -yine Şinasi'nin etkisi olduğu belli olan çekimserliği, temkini bırakarak- siyasi polemiklere sıkça girmeye başlar. 1865-1867 arasında Şinasi'nin mi yoksa Kemal'in mi değiştiği çok açık olmasa da; Mustafa Fazıl Paşa'nın organizesi ile Paris'te bir araya gelen üstat-talebe arasına bu saatten sonra bir daha hiçbir şekilde telafisi olmayacak bir soğukluk girer. Ancak Şerif Mardin bu ayrılığın ta baştan beri aslında var olduğunu, fakat Paris’te iyice nüksettiğini, Şinasi’nin liberal ve Batılı bir görüşe sahipken Kemal ve Yeni Osmanlıların daha muhafazakâr bir çizgide olduklarını, onlar için Batı'yı örnek almak ve terakki etmek gibi düşüncelerin bir araç rolünde olduğunu ifade eder. (Mardin, s. 134)

\section{Namık Kemal'de Mistik Etkiler}

Cevdet Paşa hatıratında Yeni Osmanlıları, Paris'e gitmelerinden önce Ceride-i Havadis'in yazı işlerinde bulunan Hafız Müş̧ik adında bir muhalifin yanına gidip orada sohbetler yapan bir grup genç olarak tanıtır. (İnal, s. 27-29) Ceride-i Havadis'in başyazarlarından olan Ali Âli ve Hafız Müşfik, İbrahim Kuşadalı'nın kurucusu bulunduğu bir Halvetî zümresinin müntesipleridir. (Mardin, s. 70) Abdülbaki Gölpınarlı, Kuşadalı'nın diğer bir müridinin de Kemal'e mistik anlayışı telkin eden Osman Şems olduğunu söyler. (Gölpınarlı, s. 19) Ceride-i Havadis'e takıldığı Paris öncesi dönemde Kemal'in bu kişilerden mistik anlamda ne kadar etkilendiği başka bir konu olmakla beraber, Kuşadalı'nın asıl Kemal üzerindeki etkisi "yeni tasfiyecilik" şeklinde sonraki hayatında görülür. Mardin'in "milli değerler kültünü ve militanlı̆̆ını başlatan tipik bir modern reaksiyon" olarak gündeme getirdiği bu kavram Batı'dan alınan her şeyin bize ait olan değerler kriterine tabi tutularak filtrelenmesini ifade eder. Kemal bunu Paris sonrası dönemde o kadar ileri götürür ki, savunduğu vatan, millet, hürriyet, meşveret gibi bütün yeni değerleri ya bir Kuran ayeti ile ya da bir hadis metni ile bağdaştırma gayretine girer. Mithat Cemal Kuntay Kemal'in Londra'dan babasına pek çok İslamî kaynak kitabı siparişi verdiğini nakleder. Mardin'e göre bu düşünce ile Yeni Osmanlılar; ne Şinasi'de, ne Yeni Osmanlılar'ın Avrupa'daki hamisi Mustafa Fazıl Paşa'da, ne de Onların muhalifi Âli Paşa'da olmayan "kendilerini idrak" hassasına sahip olurlar. (Mardin, s. 134) Kemal, Paris'te bu tarihten sonra İslamcı düşüncelerle İttihâd-1 İslam ve İstikbal gibi makaleleri kaleme alırken hızla 
Şinasi'nin bulunduğu saftan uzaklaşır. Ancak onda Şinasi'den miras kalan terakki düşüncesi ve daima yeniliklere açık tavrı son anına kadar hep devam eder.

\section{6. Üstad Şeyh Ahmed}

1873'te gittiği Magosa'da fikir noktasında etkilendiği üstatlarının arasına Kemal'i Şinasi'den daha da uzaklaştıracak Şeyh Ahmed adında sürgün yaşlı bir alim de girer. Magosa'da kaldığı üç yıl boyunca Şeyh Ahmed Kemal'e İslamcılık ve hürriyet düşüncesini aktarır. Kemal'in o dönemki ve sonrasındaki eserlerinde Şeyh Ahmed'in etkisinin olduğunu ve bu etkinin Leskofçalı Galip ve Şinasi'den daha derin olduğunu Süleyman Nazif ifade etmiştir. (Süleyman Nazif, s. 13) Kemal Ebuzziya'ya yazdığı mektupta ondan "Üstadımız Şeyh Ahmed Efendi Hazretleri" olarak bahseder. Kemal'in kaleme almış olduğu vatan konulu bir manzume hakkında "Bu tarzda söylenecek şiirler, bu zamana göre, siyasî vatanseverlik örnekleri niteliği taşımaktadır. Bunlar milletin zihninin açılmasına hizmet eder." diye iltifatta bulunduğunu nakleder. Kemal mektubunda Ebuzziya'dan onu yücelten bir yazı yazmasını talep eder. Bütün buraya kadar olan ifadeler Şeyh Ahmed'in Kemal için ne kadar mühim bir şahsiyet olduğunu ortaya koysa da, onu Şinasi'nin de önüne geçirecek bir hüviyette göstermez. Ancak mektupta ondan bahsettiği bölümün sonunda Şeyh Efendi'yi hürriyet taraftarlarının bir çeşit babası ve öncüsü olarak ifade etmesiyle bu ilişkinin sanıldığından daha ileri boyutlarda olduğu anlaşılır. (Ebuzziya Tevfik, s. 661-662) Dolayısıyla Kemal'in bundan sonraki hayatında hürriyet, vatan, milliyet gibi Batı kaynaklı yeni temaları İslam dini içinde temellendirmeye çalışmasının ve bu maksatla kaleme aldığı roman, piyes ve şiirlerin arka planında Şeyh Ahmed'in de önemli etkisinin olduğu açıktır. 1874'te ona yazdığı bir mektubunda kullandığ1 "Slddıkî-mizaç ve Farukî-madlab, Osmanî-imtizâc-l Alevî-neseb, Hasanî-minhac ve Hüseynî-meşreb Efendimiz Hazretleri" gibi tavsifler Kemal'in ona ne kadar değer verdiğini gösterir niteliktedir. (Göçgün, s. 180)

\section{Kemal-Ekrem-Hâmid Mektebi}

Namık Kemal ve Recaizade Mahmud Ekrem 1862'de Hariciye Mektubî Kalemi'nde tanışırlar. Bu tanışma Recaizâde'nin Encümen-i Şuara toplantılarına katılması ile pekişir. 1862'den sonra Kemal Tasvir-i Efkar'da iken Recaizade'nin de ara sıra yazıları bu gazetede çıkar. 1867'de Avrupa'ya giderken Tasvir-i Efkar'1 Recaizade Mahmud Ekrem'e emanet eder. Gazetenin 465. sayısından sonrasını Ekrem çıkarır. Şinasi 1868 'de Paris'ten döndükten sonra da bir mektupla gazeteyi ona devretmesini ister. İlerleyen süreçte Kemal İstanbul'da bulunduğunda yüz yüze, sürgünde olduğunda ise mektupla iletişim kurarlar. Kemal Recaizade'yi ve onun vasıtasıyla tanıştığ Abdülhak Hamid'i sanat ve edebiyat noktasında yönlendirmeye, yetiştirmeye çalışır. Abdülhak Hamid Londra ve Hindistan gibi ülkelerden, Kemal Midilli, Sakız gibi sürgün yerlerinden, Recaizade İstanbul'dan birbirlerine yazdıkları mektuplarla adeta bir mektep tesis ederler. Mesafelerin uzaklığ Türk Edebiyatı'nın geleceğini etkileyecek bu dostluğun gelişmesini engelleyemez. Kemal-EkremHamid mektebi diyebileceğimiz bu yapının sonraki dönemde Servet-i Fünun dergisi çevresinde toplanan Edebiyat-1 Cedîde akımının oluşmasına kapı açtığı söylenebilir.

En çok eserini nesir sahasında veren Kemal'e kıyasla Ekrem ve Hamid'in daha çok şiire yönelmelerinde, Kemal'in onları bu sahaya teşvik etmesinin büyük payı vardır. Kemal Midilli'den 1879'da yazdığı mektupta Ekrem ve Hamid'den yeni şiiri geliştirmelerini ister: "Ben nesre oldukça hizmet edebildim; fakat şiiri istediğim yola getirmekten acizim. Ĕger o muvaffakiyet mümkün ise, seninle Hamid'den beklerim." (Tansel, s. 348) Başka bir mektubunda Kemal onların vatan için yazmaları gerektiğini vurgular: "Vatan, bugün edebiyattan gördüğ̈̈ faydayı askerlikten başka hiçbir şeyden görmedi. Şinasi ahirete gitti. Beni önünüzde görüyorsanız gayret edin. Sizden kan istemiyorum, çünkü pek kolay bezl edeceğinizi bilirim. Birkaç damla mürekkep istiyorum." (Tansel, s. 379) Ancak şiirdeki ümit ettiği bu gelişmeyi, Recaizade'den çok Hâmid'de gördügüu söylenebilir. Çünkü arada gelip giden mektuplara bakıldığında Kemal'in Recaizade'yi daha çok tenkit ettiği, Hamid'in şiirini ise övdüğü göze çarpar. Recaizâde'nin eserleri arasında Kemal'in en çok ilgi 
gösterdiği eseri "Talim-i Edebiyat" adlı retorik kitabıdır. Kemal'in müsveddeleri arasında ölümünden sonra bulunup kitap haline getirilen "Talim-i Edebiyat Üzerine Risale"sinde Kemal Recaizade'yi takdir eder hem de dönemin edebiyat meseleleri hakkında yorumlar yapar. Recaizade için Kemal her bakımdan örnektir. Onun şiirlerini taklit etmeye çalışır ve bu şiirleri Kemal'e gönderir, değerlendirmesini bekler. Örneğin Kemal'in "lazımsa" redifli şiirine Recaizade yine aynı redifli bir gazelle nazire yazar ve ona gönderir. Ancak Kemal Recaizade'nin naziresini beğenmez. Yine Kemal'in Hersekli Arif Hikmet için söylediği "Cenâb-ı Hikmet-i kudsî-şi'âre dek gideriz" mısraına, Recaizade "Cenâb-ı Namık-ı kudsî-şi'âre dek gideriz" mısraıla nazire yapar.

\section{Ekrem'in Kemal'den Uzaklaşması}

Kemal Recaizade için sonuna kadar büyük üstat rolünde kalmaya devam etse de, Recaizade'nin ona katılmadığı düşünceleri de vardır. Bunların içinde belki de en önemlisi edebiyatın maksadının ne olduğudur. Kemal "Lisan-1 Osmanî’nin Edebiyatı Hakkında Bazı Mülahazatı Şamildir" başlıklı yazısında edebiyatın gayesini "hüsn-i terbiye, mekârim-i ahlak, tevsi-i kariha, muhafaza-i milliyet" olarak belirtir. (Enginün, s. 129) Recaizade, bunu kabul etmekle beraber, maksadın sadece bunlara hasredilemeyeceğini, şiirin ahlak dersi vermek için söylenemeyeceğini Takdir-i Elhan'da ifade eder. Ayrıca “Zerrattan şümûsa kadar her güzel şey şiirdir." diyerek şiirin alanını toplumsal olmaktan uzaklaştırır ve estetik alana yaklaştırır. (Enginün, s. 491) Bu farklılık, bir sonraki neslin Kemal'den uzaklaşmasına; onun dava haline getirdiği sosyal temaları, toplumsal konuları bırakmasına ve bireysel olana, doğrudan estetik biçimlere yönelmesine sebep olacaktır.

\section{Kemal'in İzinde Hâmid'in Eserleri}

Kemal'in ikinci bir öğrencisi olarak düşünebileceğimiz kişi, Şair-i Azam ünvanıyla tanınan Abdülhak Hamid Tarhan'dır. Namık Kemal Recaizade'ye yazdığı mektupta Hamid'i ilk nerede gördüğünü anlatır ve hakkındaki düşüncelerini merak eder. "Hamid Bey'in, Macerayı Aşk ve İçli Kız ünvanll iki eserini gördüm. Benim tahminime göre bu Hamid Bey, Nasuhi Bey'in küçük biraderi olacak. Avrupa'ya gitmeden bir kere, Tercüme Odası'nda görmüss idim. Avdetimden sonra da bir kere sokakta gördüm. Müşâhedâtımdan anlayışım, şimdi on dokuz veya yirmi, nihayet yirmi bir yaşında olacak! Bu hâlde oyunları kendi yazdı ise, yani sen tashih etmedin ise, -İstanbul'da senden başka o şîvede adam yoktur-demek ki çocuk, hiç olmazsa bizim kadar bir edîb olacak.. Oyunlarını, hey'et-i umûmiyyesini kabul ettim zannetmezsin ya!.. Eserlerin gerek tertîb, gerek tasvirce pek çok mu'âheze götürür yerleri var; fakat teşbih ve tahayyül ve arasıra teşrîh-i vicdan cihetleri, bizim mesleği pek ziyade andirtyor; binâenaleyh, şu suallerime cevap isterim: 1-Hamit Bey, benim bildiğim çocuk mudur? 2-Sinni, tahmin ettiğim derecede midir? 3-Eserleri tashîhden berî midir? 4Kitaplarında, onun neşriyatına dair ilanlar görüyorum; daire-i ülfet ve mahremiyetinde midir? Insan ne kadar aciz olsa, her ne cihette olur ise olsun, kendine benzer bir mahlûk görünce, mâder-i vatanın âgûş-ı terbiyesinde bir birader görmüş kadar memnun oluyor." (Tansel, s. 378-379) Başka bir mektubunda Kemal, Türk Edebiyatı'nda şiirde asıl yeniliği Şinasi ve Hamid'in yaptığını kendisinin arada bir "hatt-l ittisal" yani birleştirici bir rol oynadığını belirtir. Midilli'den yazdığı diğer bir mektubunda ise Hamid'in zihnini ve fikrini över: "Hamid, seni muhatap etmeye adından büyük bir kelime bulamıyorum! Allah zihnini güneş kadar parlak yaratmış; fikrin de ziya gibi teâlî ile muttasıf olmak kadrine daha şâyân olur. Çalış, çalıș! Ben edebiyât-ı Osmaniye için tasavvur ettiğim ulviyyâtı bin türlü hissiyât ile karıştırdım; âsârımı istediğim dereceye getiremedim. Bakalım sen getirebilir misin?.. Ben daima Şinasi'yi yâd edegeldiğim gibi, sen de Kemal'i yâd edersin." (Tansel, s. 201)

Abdülhak Hâmid'in tarihî piyeslere yönelmesinde Kemal'in özellikle de Celaleddin Harzemşah piyesinin önemli bir etkisi vardır. Hamid bu çizgide Endülüs'le ve İlhanlılarla ilgili çoğu manzum olan beşer piyes kaleme alır. Bunların özellikle de Tarık piyesinin içeriğine bakıldığında Kemal'in heyecanlı ve ateşli üslubunun etkisi hemen fark edilir. Ayrıca Hamid, Yavuz Sultan Selim'i methettiği "Kabr-i Selim-i Evvel'i Ziyaret” başlıklı şiirini yazar ve Kemal'e gönderir. Kemal şiiri 
beğenir ve hemen bir nazire kaleme alarak bir mektupla beraber Hamid'e gönderir. Mektubunda Hamid'in tarihî konularla ilgilenmesinden duyduğu memnuniyetini ifade ederek, kendisinin nesir sahasında yaptığını, onun nazım sahasında yapmasını ister: "Sen, tarih dediğimiz ummân-ı zulmetin âmak-ı hıfzına gir! Bize, Eşber gibi kitaplar yaz! İskender'in ahlakından büyük ahlak tasavvur ve tasvir et! Selim'i Evvel'in türbesini ziyaret eyle! O ziyaretindeki hissiyatı, o padişah-ı azîmü'ş-şâna nedîm-i hâs olan Hasan Can'ın vicdanından sudûr etmiş kadar ruhani bir belagatla tarif et! Selim 'i Evvel'in meziyet-i siyasiyyesini Osmanlı ashâb-ı kalemi arasında en evvel tarife nesren muvaffak olan Kemal nazmına nazîre söylemeye çalıssıı! Sana kudretin mevhibe-i mahsusası onu iktiza eder." (Tansel, s. 176) Hâmid Kemal'i tarih dışındaki konularda da örnek alır. Buna en bariz örnek İçli Klz piyesidir. Hem bu piyes hem de Recaizade'nin Vuslat', Kemal'in Zavall Çocuk piyesinden konu ve olay noktasında esinlenilerek yazılmıştır.

Hamid, Bombay'a giderken gemi Midilli’ye uğradığında, o sırada sürgün olarak orada yaşayan Kemal'le görüşür. Kemal onun yazdıklarını genel olarak beğenmekle beraber, mücadele konusunda onu pasif gördüğünden dolayı "miskin" tabirini kullanır. Bu söz Hamid'e çok dokunmuş olacak ki, sonradan Kemal'e cevap mahiyetinde bir mektup gönderir. Bu mektupta kendisinin "miskin" olmadığını, "sâkin" olduğunu, sükûtunun da daimî olmadığını, önüne bir firsat çıkarsa hiddet ve satvetle ortaya çıkacağını belirtir. Sonrasında ise Kemal'i takip ettiğini ancak tarzının farklı olduğunu ekler: "Zannetmeyiniz ki ben sizin açtığınız yola gitmiyorum. Yolum o yoldur. Fakat ben yavaş gidiyorum. Zira koşarsam düşeceğimden eminim. Düşünce gülle gibi, ylldırım gibi düşmeli.." der. (Uçman, s. 228)

\section{Mukaffa veya Mühecca Tartışması}

Kemal'le Hamid arasındaki üstat-talebe ilişkisini anlayabilmek için "mukaffa veya mühecca" tartışması önemlidir. "Macera-yı Aşk" eserinin yayınlanması üzerine Kemal Hamid'i tebrik eder. Ayrıca ona yeni tarzları denemesini ve "bizim parmak hesabi" diye bahsettiği hece veznini, bu gibi dramatik nazım şeklindeki eserlerinde denemesini tavsiye eder. Hamid bir sonraki eseri Nesteren'de acemice de olsa hece veznini kullanmış ancak ne Kemal'i ne de Ekrem'i memnun edebilmiştir. Kemal bir mektupla eserin konusunu, sonucunu, ifadesini, garip kelimelerini beğenmediğini, ümitsizliğe kapıldığını, hecenin dramatik nazma uygun olmadığını anladığını belirtir. Bütün bunlarla beraber yeni tarzları denemesi konusunda Hamid'i teşvik etmeyi de unutmaz: "Sen de bir kere vezinleri, kafiyeleri karlştır... Kafiyesiz yolları daha ziyade dikkatle karlştır. Hangi yolu, Türkçede dramatik şiir tertibine daha müsait görürsen bir narration yap gönder. İş̧allah muvaffak olursun." (Tansel, s. 375) O sırada Osmanlı matbuatında da Nesteren hakkında Elhac İbrahim Efendi ve Kemalzâde Said Bey'in başını çektiği bir eleştiri yağmuru başlar. Tercüman-ı Hakikat'te Ahmed Midhat Efendi, Hamid taraftarlarının tepkisini çekmemek için konuyu yatıştırmaya çalışsa da mesele uzar. Hamid bu tartışmalar esnasında en çok Kemal ve Ekrem'in suskunluklarına, kendisini matbuata karşı savunmamalarına alınır. Kemal bir mektup yazarak Hamid'i eleştirilere cevap vermemeye davet eder ve onu teselli eder: "Zannetmem ki sen müteessir olasın, elbette olmamışsındır! Belki uğradığın ta'rizlerle iftihar etmişsindir." diyerek onu tenkit edenlerin onun en beğenmedikleri beytine bir nazire bile söylemeyeceklerini yazar. (Tansel, s. 203) Hamid, bunun üzerine Ekrem'e konu hakkında serzenişte bulunan uzun bir mektup yazar. Karşılıklı atışmalar devam edince Kemal tekrar araya girerek bu tartışmayı uzatmamalarını söyler ve onları susturur. Ancak bu tartışma Hamid ve Recaizade'nin arasını açamaz, zaten Hamid kendisine yöneltilen haklı eleştirileri kabullenmiş, yalnız Ekrem'in "tezyif-gûne" üslubuna takılmıştır.

\section{Ekrem-Hâmid Etkileşimi}

Kemal'in öğrencileri Ekrem ve Hamid de birbirlerinden etkilenirler. Zaten Hamid'i Kemal'e tanıtan ve mektuplarında aracılık yapan Ekrem'dir. Ancak şiir ve sanat noktasında Hamid'in Ekrem'e öncülük ettiği açıktır. Hamid bu devrede denediği yeni şekil ve üslup tarzlarıyla sadece Ekrem'i değil, bütün bir nesli etkilemiştir. Sonraki nesil üzerinde daha çok Ekrem'in üstatlığı, Hâmid'in ise 
çok sayıdaki yetkin eserleri etkilidir. Recaizade'nin en meşhur eseri olan Araba Sevdası'nda da, Hamid'in manzum bir aşk hikâyesi olarak kaleme aldığ 1 Garam'ın etkisi vardır. Birbirine benzeyen iki kız kardeşten birine âş̧k olan ve sonra onları birbirine karıştıran âş̧ figürü ve boş ya da yanlış mezar başında ağlama motifleri ile aşk-ölüm ikilisinin karikatürize edilmesi her iki eserde de oldukça benzerdir.

\section{Sonuç}

Tanzimat döneminde halkalar şeklinde devam eden üstad-talebe zincirinin merkezinde muhakkak ki Namık Kemal yer almaktadır. Kemal'in üzerindeki en belirgin etki Şinasi'ye aittir. Sade dil ve Batı'dan alınan yeni temalar konusunda Şinasi öncü rol oynarken, Tanzimat Edebiyatı'nı şekillendirecek olan Kemal onunla sinırlı kalmaz. 19. Yüzyılda klasik edebiyatı devam ettiren Leskofçalı Galip'ten, Halveti tarikatından İbrahim Kuşadalı ve Osman Şems'e, Magosa'da tanıştı̆̆ Şeyh Ahmet'e kadar farklı etkiler onda söz konusu olur. Kemal farklı etkiler altında yeni gelişen bir edebiyatı şekillendirirken diğer taraftan da kendisinden sonraki nesli hazırlamaya çalışır. Uzak mekanlardan birbirleriyle mektupla haberleşen Kemal, Ekrem ve Hamid arasında oldukça seviyeli ve edebî bir ilişki yaşanır. Kemal onlara kendi sosyal ve siyasi düşüncelerini çok benimsetemese de, yeni şiir sahasında Şinasi ile onların arasında mükemmel bir köprü görevini ifa eder. Kemal'in Şinasi'den bazı konularda ayrılıp uzaklaştı̆̆ı gibi, Ekrem'in de Kemal'den ayrı düştüğü konular olur. Tanzimat dönemindeki bu halkalar şeklinde devam eden üstat-talebe ilişkisi bir sonraki döneme Recaizade'nin öğrencisi Tevfik Fikret ve Servet-i Fünuncularla devam eder. Fikret'in şiir dilinin oluşmasında Recaizade'nin etkisi oldukça yükssek olduğu gibi, diğer Servet-i Fünuncularda da daha çok Hamid'in etkisi görülür. Aslında Hamid'in yeni tarzları cesaretle ve maharetle denediği şiirleri kendisinden sonraki bütün şairleri etkilemiş, Türk şiirinin seyrinde önemli bir kırılma meydana getirmiştir. Diyebiliriz ki eski şiiri mezara koyup yeni bir şiir tarzını velût mizacıyla ortaya koyan şair Abdülhak Hamid olmuştur. Üstad-talebe ilişkisi ile şekillenen yeni şiir anlayış1 Fikret'in öğrencisi Ahmet Haşim'le Cumhuriyet dönemine kadar uzanır.

\section{Kaynakça}

Ebuzziya Tevfik. (1306). Kemal. İstanbul.

Ebuzziya Tevfik. (1973). Yeni Osmanlılar Tarihi. (Ş. Kutlu, Dü.) İstanbul: Hürriyet Yayınları.

Enginün, İ. (2006). Yeni Türk Edebiyatı Tanzimat'tan Cumhuriyet'e. İstanbul: Dergah Yayınları.

Enginün, İ. (2011). Yeni Türk Edebiyatı Metinleri 3. İstanbul: Dergah Yayınları.

Göçü̈n, Ö. (2014). Namık Kemal. Ankara: Akçağ Yayınları.

Gölpınarlı, A. (1942). Namık Kemal'in Şiirleri. Namık Kemal Hakkında (s. 13-77). içinde İstanbul: D.T.C.F. Yay.

İnal, İ. (Haziran-Ağustos 1929). Hafiz Müşfik Efendi. Türk Tarih Encümeni Mecmuası, I(1), 27-29.

Kaplan, M. (1948). Namık Kemal: Hayatı ve Eserleri. İstanbul: İstanbul Üniversitesi Edebiyat Fakültesi Yayınları.

Kaplan, M. (2005). Şiir Tahlilleri. İstanbul: Dergah Yayınları.

Mardin, Ş. (2012). Yeni Osmanlı Düşüncesinin Doğuşu. İstanbul: İletişim Yayınları.

Süleyman Nazif. (1340). Namık Kemal. İstanbul: İkdam Matbaası.

Tanpınar, A. (2003). 19'uncu Asır Türk Edebiyatı Tarihi. İstanbul: Çağlayan Kitabevi.

Tansel, F. (1967). Namık Kemal'in Hususi Mektupları (Cilt I). Ankara: Türk Tarih Kurumu. 
Tansel, F. (1967). Namık Kemal'in Hususi Mektupları (Cilt II). Ankara: Türk Tarih Kurumu.

Tansel, F. (1967). Namık Kemal'in Hususi Mektupları (Cilt III). Ankara: Türk Tarih Kurumu.

Tansel, F. (2005). Hususi Mektuplarına Göre Namık Kemal ve Abdülhak Hamid. Ankara: Akçağ Yayınlar1.

Uçman, A. (2006). Namık Kemal. İ. Çetişli içinde, Tanzimat Edebiyatı (s. 201-288). Ankara: Akçă̆ Yayınları. 